\title{
Livelihood activities in a Namibian wildlife conservancy: a case study of variation within a CBNRM programme
}

\author{
WILLIAM KAN A PA UX and BRIAN CHILD
}

\begin{abstract}
Approaches to community-based natural resource management tend to vary among programmes based on the needs and characteristics of the communities in which the programmes operate. Variation also exists within individual programmes, creating the potential for conflict if management does not recognize that these differences can indicate competing interests and needs. In this study we examine livelihood activities at the household level in a wildlife conservancy along the Kwando River in the Caprivi region of Namibia. We ask how people in the conservancy make their livelihoods and what differences exist between the conservancy's riverside and inland populations. The study finds that the inland population, c. $20 \mathrm{~km}$ from the river on slightly heavier soils, engages in fewer livelihood activities and has greater food security than does the riverside population. We further establish that differences between the two populations are significant enough to indicate two distinct combinations of livelihood activities with different environmental interactions. These findings suggest that any management action taken by the conservancy will affect household livelihoods differently based on location and that these differences must be considered if the conservancy is to make a successful transition from a subsistence-based agricultural system to a wildlife-based economy.
\end{abstract}

Keywords CBNRM, food security, human-wildlife conflict, livelihoods, Namibia

This paper contains supplementary material that can be found online at http://journals.cambridge.org

\section{Introduction}

Community-based natural resource management $\checkmark(\mathrm{CBNRM})$ programmes have been present in southern Africa since the 1980s. CBNRM seeks to develop mechanisms that allow financial benefits from tourism and safari

William Kanapaux (Corresponding author) School of Natural Resources and the Environment, PO Box 116350, University of Florida, Gainesville, Florida 32611-6350, USA. E-mail kanapaux@ufl.edu

BRIAN CHILD Center for African Studies \& Department of Geography, University of Florida, Gainesville, Florida, USA

Received 30 January 2010. Revision requested 22 April 2010.

Accepted 4 June 2010. First published online 21 June 2011. hunting to be captured by local communities and distributed to their residents. These conservancies are viewed as tools for simultaneously achieving biological conservation and economic development. Under these programmes management of wildlife and other natural resources on communal lands becomes the responsibility of local communities.

The Nature Conservation Amendment Act of 1996 paved the way for Namibia's CBNRM programme. The act called for the collective management of wildlife and tourism through a common property resource management institution known as a conservancy. Rural communities were given rights to use and benefit from wildlife and to receive tourism concessions as an incentive for conserving wildlife (Jones \& Murphree, 2001).

Approaches to CBNRM tend to vary from programme to programme, based on the unique needs and characteristics of the communities involved (Taylor, 2009). Variation also exists within individual programmes, creating the potential for conflict if management does not recognize these differences and the presence of competing interests and needs. Few communities exist as homogeneous entities but instead contain divergent interests with multiple actors and interactions (Agrawal \& Gibson, 1999). A locally based institution must present itself as credible to all resource users and stakeholders and this requires taking actions that are not perceived as marginalizing a particular segment of stakeholders (Pero \& Smith, 2008). Institutions that do not recognize differences can disrupt existing physical and social spaces or allocate rights and obligations in ways that replicate old patterns of discrimination $(\mathrm{Li}, 2002)$. They also run the risk of ignoring or simplifying the diverse set of formal and informal institutions that shape access to environmental resources and services (Leach et al., 1999).

Sallu et al. (2009) found that social complexity within rural settlements can lead to unequal distribution of CBNRM benefits based on access to natural resources. Likewise, programmes that lack financial accountability cannot guarantee that benefits are distributed equally (Baker, 1997). Consequently, the number of people who cannot secure tourism jobs or other benefits from tourism could be significantly larger than the number who can, creating the potential for resentment and consumptive land-use practices (Vanderpost, 2006). However, community perspectives on equity in terms of benefit distribution and cost allocation may differ from how outsiders perceive equity (Cochran \& Ray, 2009). These potentially complicating factors require 
a close examination of individual CBNRM programmes to make sure that goals and outcomes are properly aligned with all stakeholders' expectations.

Here we look at spatial differences in livelihood activities that suggest a need for a management approach that recognizes variation within individual programmes and how that variation affects different community members in terms of the programme's costs and benefits. We examine local livelihoods in the CBNRM area known as Mashi Conservancy, which borders the Kwando River in Namibia's East Caprivi region (Fig. 1). The Conservancy is remote, economically undeveloped and has a wildlife population that is recovering from years of poaching. Its people subsist primarily on rain-fed agriculture on sandy soils in a semi-arid drought-prone environment.

CBNRM has brought potential for significant changes to rural livelihoods in the Kwando region. Seeking to provide incentives for local people to manage wildlife populations better, it operates on the premise that if communities are given sufficient authority and control over wildlife, the benefits will outweigh the costs (Jones et al., 2002). One of CBNRM's goals is to improve the economic welfare of local people by moving away from marginal forms of agriculture and focusing on less extractive land uses that benefit from the region's biological resources (Walker, 1999). Community conservation is seen as an insurance policy against drought by spreading risk across more livelihood options (Jones \& Murphree, 2001).

The hunting and viewing of game animals in the wild play an important economic role in southern Africa's semiarid regions (Barnes, 1999, 2001; Humavindu \& Barnes, 2003). For communal areas, linking wildlife systems to tourism can generate wealth without the biological limits of pastoral and ranching systems (Cumming, 1999). In 2000 nearly $25 \%$ of income from safari hunters in Namibia accrued to the rural poor, making the industry important for economic development. Barnes et al. (2002) reported that Namibia's conservancies are economically efficient and have a high likelihood of being sustainable.

The Kwando River serves as an important wildlife corridor for elephants Loxodonta africana and other game species that migrate north from Botswana and to a lesser extent south from Angola and Zambia. The land area spanning Namibia's Caprivi region, northern Botswana and western Zimbabwe contains Africa's largest population of elephants and one of the largest stretches of known elephant range on the continent (Skarpe et al., 2004; Blanc et al., 2007). The total population is estimated at c. 180,000 elephants and appears to be growing at 5.4\% annually (Blanc et al., 2005). These elephants serve as a major draw for both tourists and safari hunters. For conservancies such as Mashi they represent huge earning potential but also pose a threat to local crop production and other forms of livelihood.

Over the past 2 decades doubts have been raised about CBNRM's ability to achieve the dual objectives of biological conservation and economic development (Hackel, 1998; Agrawal \& Gibson, 1999; Kiss, 2004). Previous studies have found that CBNRM programmes have had difficulty improving the livelihoods of local people whilst also conserving wildlife (Murphree, 2004). In cases where a CBNRM programme does distribute cash benefits to households, some beneficiaries may then invest in land uses that conflict with wildlife, such as field expansion and additional livestock (Murombedzi, 1999).

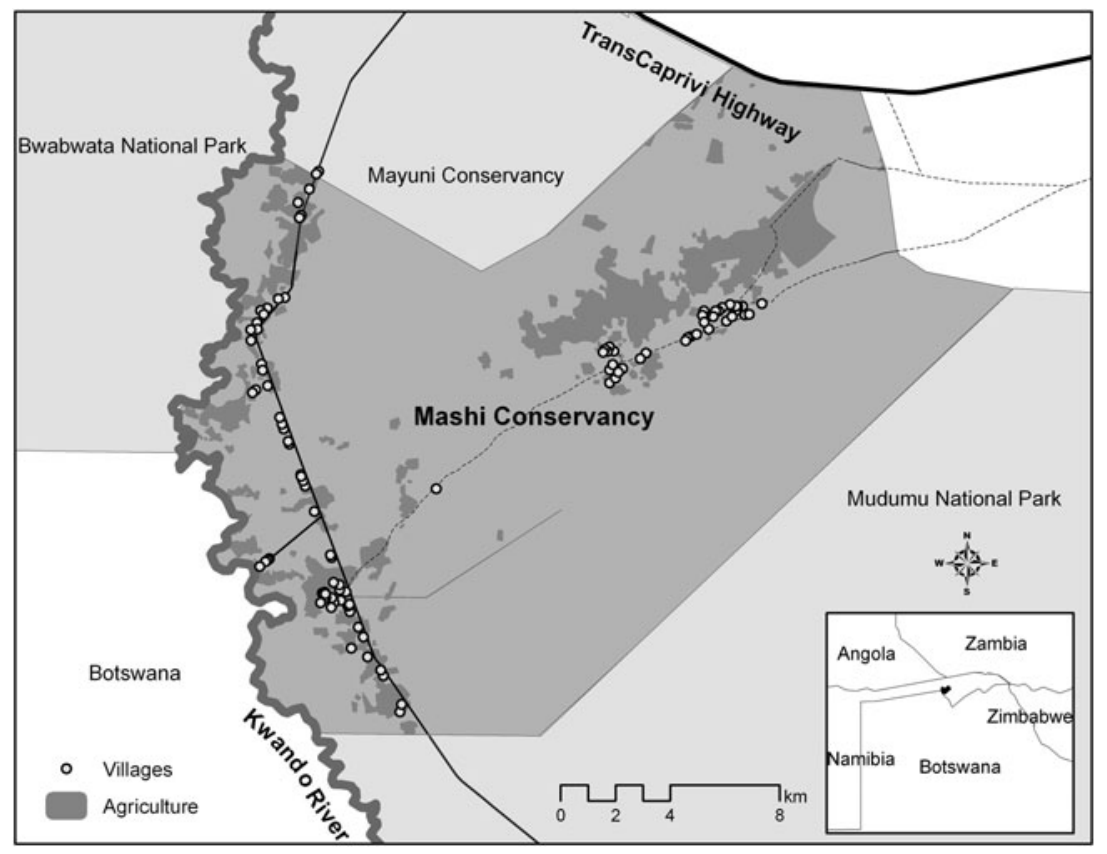

FIG. 1 Villages in Mashi Conservancy, showing the two distinct population areas: one along the river on a graded road and one inland along a rough track. The inset shows the location of Mashi Conservancy in Namibia. 
CBNRM proponents, however, believe that abandoning efforts to combine conservation and poverty reduction would be premature (Adams et al., 2004). At the local scale different interests must be reconciled to succeed in managing natural resources sustainably. This task is urgent given that lands bordering protected areas experience significantly higher levels of human population growth than do other rural areas (Wittemyer et al., 2008). Although CBNRM programmes have a mixed track record, many see them as the only real option for successfully managing natural resources (Torquebiau \& Taylor, 2009).

Individual livelihood strategies are often complex and dynamic, and CBNRM changes the structure of those activities (Twyman, 1998). CBNRM shifts livelihood activities such as hunting from the individual sphere to the communal sphere and thus alters the individual's relationship to the environment and its resources (Twyman, 2000). Musumali et al. (2007) found that a majority of community members in northern Botswana and Zambia reported receiving no benefits from their CBNRM programmes at the household level. Those communities had unfulfilled expectations resulting from confusion over the role of CBNRM institutions and the kinds of benefits that could be expected from them.

These and other studies point to the need for a more careful approach to CBNRM that accounts for livelihood activities at the household level. To that end, we examine data from 60 household livelihood surveys conducted in June and July 2007 in Mashi Conservancy. It focuses on two areas: one along the Kwando River and the other c. $20 \mathrm{~km}$ inland. The Conservancy was officially gazetted in 2003. It is bordered on two sides by national parks and has a growing population of elephants and other wildlife (IRDNC, 2007). This increase in wildlife has also brought an increase in crop raiding. The combination of crop raiding, poor soils and variable rainfall makes food security a serious concern, especially for households closest to the river.

\section{Study area}

Mashi Conservancy has a population of c. 4,000 residents living in $>100$ villages (Fig. 1 ). The Conservancy's two population areas are distributed along two roads. The riverside population is along a graded road that connects to the Trans-Caprivi Highway c. $20 \mathrm{~km}$ to the north. The highway serves as the major artery between the rest of Namibia and Caprivi's administrative capital and main market, Katima Mulilo, c. $120 \mathrm{~km}$ to the east. The graded road runs parallel to the Kwando River. Villages and settlements are clustered on sandy soils along the road, which is a throughway for tourists heading south to neighbouring Mudumu National Park.

Mashi's inland population is connected to the graded road by a $20-\mathrm{km}$ track through fields and bush. These settlements are situated to the east on more fertile soils that have a higher content of clay. The inland population is more densely clustered than the riverside population and has larger agricultural fields. Although inland villages appear to be remote in relation to the riverside villages, they are actually closer to the Trans-Caprivi Highway and Katima Mulilo via tracks on the Conservancy's eastern boundary. The remainder of the Conservancy is largely unsettled and consists of shrub, forest and grassland. Some cattle owners from the inland area drive their herds through this area to the Kwando River during the dry season for water.

\section{Methods}

This study relies primarily on a household livelihood survey that collected information on demographics, household size and structure, number and kinds of assets, incomeproducing activities, subsistence activities, livestock ownership, crop production, food security and human-wildlife conflict. Local research assistants were employed to help collect the information.

To achieve a random sample of Conservancy households we conducted a village and household census of the entire Conservancy, with the exception of a handful of villages in a distant section bordering the Trans-Caprivi Highway. This census served as our sampling frame. In each village the headman or his representative was asked permission to include the name of the village, count the number of households and take coordinates, with a global positioning system (GPS), of its location. Only three villages refused permission. The sampling frame comprised 103 villages, ranging in size from two households to $>50$.

The riverside area had 63 villages with 517 households and was divided into three village clusters. The inland area had 40 villages with 444 households and was divided into two clusters. Each village cluster was assigned a weight based on its proportion of villages to the population area. This weight determined the number of surveys to be conducted within that cluster. Individual villages were given equal weight regardless of size to avoid sampling bias towards the largest villages.

Villages were selected through a random number generator, as were households within selected villages. Duplicate selections of a village were allowed. Alternate villages and alternate households were also randomly selected prior to conducting the surveys. Households were identified by number, counting clockwise from the left at the entrance into the village. We conducted 60 surveys of randomly selected households, 30 in each of the two population areas, in June and July 2007. The survey (Appendix 1) comprised 53 questions that took c. 45 minutes to complete. Coordinates, obtained with a GPS, were recorded for each survey.

A follow-up field survey (Appendix 2) was administered to 10 of the 60 household survey respondents. These 10 
respondents were randomly selected, five each in the two locations. We measured the distance from household to field and the size of the field, with GPS tracking, and collected information on plot characteristics, agricultural practices and experiences with drought and wildlife conflict.

\section{Results}

A total of 60 respondents were interviewed (Table 1). The majority were affiliated with two tribes: Mbukushu (47\%) and Mafwe (43\%). Households affiliated with the two tribes are evenly distributed among the two main population areas. Nearly all respondents grew crops in 2007, primarily maize, sorghum, melons and millet (Table 2). Farmers practice rain-fed agriculture with little fertilizer use. Only two respondents who farmed in 2007 (3\%) reported using commercial fertilizer. Only five farmers, all from the inland area, reported using cattle manure.

Household livelihood activities differed significantly between riverside and inland populations by number and type. Riverside households reported a mean of 6.9 livelihood activities during the previous 12 months whereas inland households reported a mean of 4.7 livelihood activities (Mann-Whitney $U$ test, $z=-4.76, \mathrm{P}<0.01$ ). The kind of activities reported by riverside households reflects their proximity to wetland resources and tourism activities (Fig. 2). Inland households reported more cattle and more income. More than half of inland households surveyed (57\%) reported owning cattle, with a mean of 15.9 head of cattle per household, whereas $27 \%$ of riverside households reported owning cattle, with a mean of 2.5 head of cattle per household.

Inland households reported significantly higher levels of income. Median annual income for riverside households was USD 89 (NAD 625). Median annual income for inland households was USD 634 (NAD 4,440, equal to the annual government pension per individual). This difference in median incomes is significant (Mann-Whitney $U$ test, $z=1.74, \mathrm{P}<0.05)$.

Inland households had greater food security than riverside households. Respondents were asked whether the household had grown enough food to feed the family

TABLE 1 Demographic information for the 60 household respondents, 30 along the Kwando River and $30 \mathrm{c} .20 \mathrm{~km}$ inland (Fig. 1).

\begin{tabular}{lccc}
\hline Household characteristics & River & Inland & All \\
\hline Mean age (years) & 40.1 & 49.9 & 45 \\
Mean years of education & 4.8 & 2.1 & 3.5 \\
Mean no. of household members & 4.0 & 3.8 & 3.9 \\
Mean no. of children under age 15 & 1.7 & 1.2 & 1.5 \\
\% Conservancy membership & 57 & 30 & 43 \\
\% married & 60 & 70 & 65 \\
\hline
\end{tabular}

TABLE 2 Percentage of households growing crops in 2007, 30 along the Kwando River and 30 c. $20 \mathrm{~km}$ inland (Fig. 1).

\begin{tabular}{llll}
\hline Crop & River (\%) & Inland (\%) & All (\%) \\
\hline Maize & 87 & 93 & 90 \\
Sorghum & 47 & 53 & 50 \\
Melons & 33 & 50 & 42 \\
Millet & 23 & 57 & 40 \\
Beans & 23 & 43 & 33 \\
Pumpkins & 17 & 33 & 25 \\
\hline
\end{tabular}

for each of 5 years from 2003 to 2007. Replies for 2007 were overwhelmingly negative in both riverside and inland populations (o and $7 \%$, respectively), indicating drought in that year. Three of the previous 4 years showed significant differences between the two main population areas (Table 3). The majority of inland households reported growing enough food for their families in each of the previous 4 years. Riverside households, on the other hand, reported growing enough food for their families less than half the time in all years.

In addition to drought, crop raiding by wildlife also poses a threat to food security. Respondents in both areas expressed concerns about increasing wildlife numbers and increased incidents of crop raiding. Ninety-five percent of households growing crops in 2007 reported crop raiding by wildlife. More than $75 \%$ of households in both areas reported crop raiding by elephants (Fig. 3).

There were also differences between riverside and inland households in number of crops grown, years of field ownership, distance to field and size of field (Table 4). Riverside households grew significantly fewer crops. Nearly all households in both locations grew maize $(87 \%$ riverside and $93 \%$ inland) but fewer riverside households grew millet, a drought-resistant crop, than did inland households ( 23 vs $40 \%)$. Years of field ownership was significantly lower in riverside than inland households. Riverside households were significantly closer to their fields, and mean field size significantly smaller, than inland households.

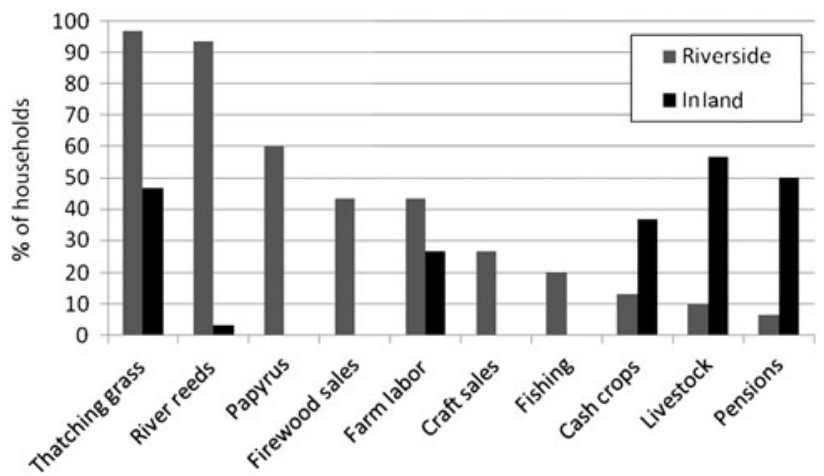

FIG. 2 Percentage of Mashi Conservancy households along the river and inland (Fig. 1) engaging in livelihood activities such as the collection of plant species for construction materials. 
TABLE 3 Proportion tests for food security (riverside community vs inland community; Fig. 1) based on responses to whether surveyed households grew enough food to feed the family in that year.

\begin{tabular}{lcccl}
\hline Year & Riverside (\%) & Inland (\%) & Test statistic & $\mathrm{P}$ \\
\hline 2007 & 0 & 7 & 2.07 & 0.15 \\
2006 & 40 & 87 & 14.07 & 0.00 \\
2005 & 33 & 63 & 5.41 & 0.02 \\
2004 & 25 & 55 & 5.39 & 0.02 \\
2003 & 46 & 55 & 0.44 & 0.51 \\
\hline
\end{tabular}

In total $43 \%$ of survey respondents claimed to have registered as a member of the Conservancy. Membership rates were significantly higher for riverside than inland households (57 vs 30\%; two proportions $\chi^{2}$ test, $t=4.34, \mathrm{P}<0.05$ ).

\section{Discussion}

Differences between the two areas show that households located along the river interact in fundamentally different ways with their environment compared to households located inland. Each population exhibits a distinct set of livelihood activities and is likely to respond differently to stressors and shocks, such as drought, flooding, human-wildlife conflict and competition for land brought on by population growth. The inland population shows a reliance on government pensions and cash crops, suggesting stability through connections with government agencies and regional markets. The riverside population, however, relies on a broader range of livelihood activities based on resource extraction.

The more diverse set of livelihood activities for riverside households provides a buffer from environmental shocks

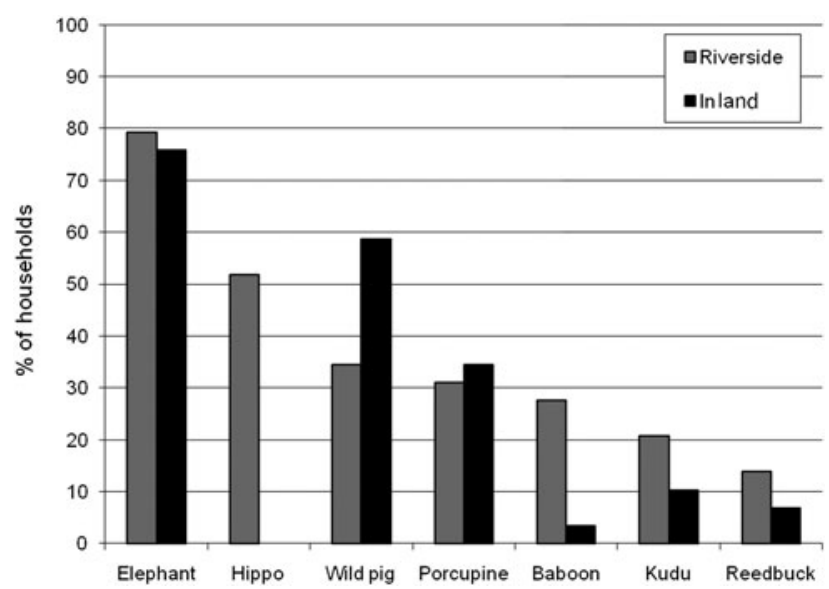

FIG. 3 Percentage of Mashi Conservancy households along the river and inland (Fig. 1) reporting crop raiding. The most commonly reported species are elephant Loxodonta africana, hippo Hippopotamus amphibius, wild pig Phacochoerus africanus, porcupine Hystrix africaeaustralis, baboon Papio ursinus, kudu Tragelaphus strepsiceros and reedbuck Redunca arundinum. and reflects the need for a greater range of activities given the poor soils. It also suggests that the riverside population is better positioned to take advantage of the economic benefits from tourism along the river and in the national parks, such as employment opportunities and demand for firewood, thatching grass and river reeds. However, population growth along the river could exceed economic opportunities provided by tourism, placing greater pressure on existing natural resources. An increase in tourismrelated demand for construction materials and firewood could also lead to unsustainable resource extraction in certain areas.

Results regarding food security raise questions about the strategies households use to survive in years without adequate harvests. Achieving food security seems especially difficult along the riverside, where both crop production and income are lower. This shortfall could be overcome through a combination of in-kind payments, assistance from relatives, greater reliance on veldt products, fishing and illegal hunting. These kinds of responses in years with low crop production can have a major impact on land and resource use.

Across Mashi Conservancy increased crop raiding by wildlife must also be considered. Caprivi residents perceive that human-wildlife conflicts, mostly in the form of crop raiding, have increased since CBNRM began (Mulonga et al., 2003). According to Mulonga et al. (2003) elephants are responsible for $75 \%$ of reported crop damage in Caprivi, a finding that is consistent with reports from survey respondents in this study. Human-wildlife conflicts deepen poverty by reducing both food supplies and options for earning cash. The problem worsens as wildlife becomes habituated to deterrent strategies such as drum beating and fire (O'ConnellRodwell et al., 2000). Survey respondents confirmed this, reporting that elephants have become aggressive towards farmers who try to keep them out of fields.

Inland household survey respondents spoke of the presence of elephants in places where none had been found in previous years, suggesting that crop-raiding pressures are increasing for the inland population. This could pose a serious problem because the interior lacks the diversity of resources found along the river. However, people in the interior appear to have more cash and assets, indicating economic linkages that provide resilience in the face of declining harvests from crop raids and drought.

As conservancies succeed at managing for wildlife they must contend with the increase in conflicts between wildlife and humans, especially crop raiding by elephants (Osborn \& Parker, 2003). Most methods to reduce such conflicts have proven to be either too expensive or ineffective, and integrated management solutions are required that involve local farmers using low-tech solutions such as buffer zones of unpalatable crops and cowbells attached to string fences (Osborn \& Parker, 2003). Only 4 years old at the time of 
TABLE 4 Mann-Whitney $U$ test for differences in agricultural practices by riverside and inland households (Fig. 1). The first two items were asked of all household survey respondents. The last two items were measured during follow-up surveys with selected households.

\begin{tabular}{llrr}
\hline Variable & Riverside mean \pm SE & Inland mean \pm SE & $Z$ value \\
\hline No. of crops grown $(\mathrm{n}=60)$ & $2.5 \pm 0.25$ & $3.5 \pm 0.34$ & -2.22 \\
Years owned field $(\mathrm{n}=60)$ & $5.2 \pm 0.84$ & $9.4 \pm 1.39$ & 2.35 \\
Distance to field, $\mathrm{km}(\mathrm{n}=10)$ & $0.5 \pm 0.24$ & $3.2 \pm 0.32$ & -2.51 \\
Field area, ha $(\mathrm{n}=10)$ & $2.5 \pm 0.54$ & $5.3 \pm 1.03$ & -1.99 \\
\hline
\end{tabular}

our survey, Mashi Conservancy had yet to develop an institutionalized approach to reducing these conflicts.

The differences between riverside and inland households point to different human-environment interactions with different consequences for each location. Riverside households occupy fields for fewer years than do inland households and have smaller fields closer to their villages. This suggests a quick turnover of land used for crop production as nutrients in the soil are exhausted. This practice could result in negative effects such as bush encroachment as fields are abandoned. At lower human population levels this strategy could prove effective in dealing with infertile soils but at higher population levels it could mean that land is exhausted more quickly.

If efforts by the Conservancy to strengthen community benefits from wildlife are successful, riverside populations may turn away from crop production to focus on economic opportunities from tourism and safari hunting. This could also attract population growth and a larger presence of cattle as personal wealth increases, adding to existing pressures on land use.

Inland households have larger agricultural fields further from the village that they have owned for a longer time. This suggests these fields are sufficiently productive to outweigh the additional costs of travel time and effort to plough, plant, guard and harvest. The higher number of crops grown in inland fields reinforces the finding that cash crops are a viable livelihood activity there. However, the combination of increased crop raiding by wildlife and human population pressures could change that.

The difference in rates of Conservancy membership between the two locations is consistent with these agricultural differences. Inland farmers stand to lose more from crop raiding than they gain from the Conservancy. Riverside households, on the other hand, gain from a number of opportunities created by tourism and safari hunting.

The establishment of the Conservancy signals a potential shift from a subsistence-based agricultural system to a wildlife-based economy. For some households this shift represents a boost in income. Conservancy and tourism jobs on average pay better than all other reported income with the exception of pensions. The Conservancy is also likely to bring other benefits that are difficult to measure at the household level, such as an increase in development projects. However, Mashi Conservancy comprises two populations with distinct combinations of livelihood activities, and these differences must be taken into account by Conservancy management (Table 5).

Small-scale community-based conservation programmes could ultimately prove to be important for poverty alleviation (Sanderson \& Redford, 2003) and a reduction in poverty should help alleviate adverse effects on the environment from livelihood pressures (Kgathi et al., 2006). But even in cases where tourism and safari hunting provide sufficient incomes

TABLE 5 Summary of key findings for riverside and inland communities (Fig. 1) and management implications.

\begin{tabular}{|c|c|c|c|}
\hline Variable & Riverside & Inland & Implications \\
\hline \% Conservancy membership & 57 & 30 & $\begin{array}{l}\text { Conservancy support is strongest along the riverside, where people } \\
\text { stand to gain most from a wildlife-based economy }\end{array}$ \\
\hline $\begin{array}{l}\text { Average number of livelihood } \\
\text { activities }\end{array}$ & 6.9 & 4.7 & $\begin{array}{l}\text { Livelihood activities are more diverse along river \& rely more on } \\
\text { area's natural resources }\end{array}$ \\
\hline$\%$ owning plough & 13 & 67 & Inland households are generally wealthier than riverside households \& \\
\hline$\%$ owning cattle & 27 & 50 & are better equipped for crop production \\
\hline$\%$ food secure in 2006 & 40 & 87 & Inland households are better able to grow enough food for their \\
\hline$\%$ food secure in 2005 & 33 & 63 & families, a situation that could be threatened by increasing wildlife \\
\hline$\%$ food secure in 2004 & 25 & 55 & $\begin{array}{l}\text { numbers. Poorer soils in riverside areas indicate need to find } \\
\text { alternative means of earning livelihoods. }\end{array}$ \\
\hline$\%$ crop raiding by elephants & 79 & 76 & Both areas reported an increase in crop raiding by wildlife. Distance \\
\hline$\%$ crop raiding by any wildlife & 97 & 93 & from river does not appear to reduce threat of crop raiding by \\
\hline$\%$ increase in crop raiding & 96 & 93 & elephants. \\
\hline$\%$ growing maize & 87 & 93 & Maize, a potential cash crop, is popular in both areas despite its \\
\hline$\%$ growing millet & 23 & 57 & $\begin{array}{l}\text { sensitivity to drought. Millet, which is drought resistant, was planted } \\
\text { more frequently inland. }\end{array}$ \\
\hline
\end{tabular}


for survival, households are likely to continue investing time and effort in diverse livelihood activities for protection against the risk of job loss. Cattle raising in particular is often seen as insurance against unemployment (Berzborn, 2007), as cattle can be used to plough, and provide manure for fertilizer, and meat and milk (Barrett, 1991). An increase in cattle production would decrease the amount of land used for wildlife and probably increase the risk of human-wildlife conflicts.

Adams \& Hulme (2001) asked how trade-offs between biodiversity conservation and local livelihoods should be negotiated among the diverse objectives of different stakeholders. One answer is that CBNRM's benefits at the household level need to be strong enough to keep local people from seeking economic alternatives and land-use options that damage conservation (Hackel, 1998; Du Toit, 2002).

Conservancies have emerged as an institutional presence that must interact with government, traditional authorities and customary livelihood practices. Relevant socio-ecological information and decision support tools improve the chances of success for community-based conservation programmes in managing wildlife sustainably (Du Toit, 2002). Lambin et al. (2001) observed that changes in economic conditions mediated by institutional factors are the main drivers of land-use change. Understanding how people within a conservancy make their livelihoods is a first step towards understanding how the conservancy could shape future livelihood strategies and land-use decisions.

CBNRM takes place on a case-by-case basis. Human population pressures, levels of resource extraction and the extent to which an ecosystem can be expected to provide resources must all be considered in making management decisions (Fortmann et al., 2001). At the local level reliability is the primary concern. Everything hinges on the success or failure of a household's livelihood activities, and these activities in large part are determined by factors beyond the household's control. CBNRM programmes must take this into account. Many households perceive the conservancy's actions to directly or indirectly threaten their livelihoods and limit the household's options for responding to threats such as crop raiding. A management approach that seeks to address variation in livelihood systems within a CBNRM programme's boundaries could help solve these problems by more closely aligning programme goals with livelihood needs at the household level.

\section{Acknowledgements}

This research was part of a larger collaborative project funded by the US National Science Foundation (NSF), the University of Florida (UF) and IUCN. Additional NSF funding was provided through an Integrative Graduate Education and Research Traineeship Program at UF on the Adaptive Management of Water, Wetlands and Watersheds (NSF Grant No. 0504422). The Caprivi-based In- tegrated Rural Development and Nature Conservation, the Namibian Ministry of Environment and Tourism and the management staff at Mashi Conservancy provided valuable assistance. In particular, we thank conservancy manager Joubert Muchaka, conservancy secretary Obey Lifumbela, and Lucious Lunyandile for their help. Two research assistants, Elvis Wamui Diamani and Noricah Likeleli, played key roles in making this study possible.

\section{References}

Adams, W.M., Aveling, R., Brockington, D., Dickson, B., Elliott, J., Hutton, J. et al. (2004) Biodiversity conservation and the eradication of poverty. Science, 306, 1146-1149.

Adams, W. \& Hulme, D. (2001) If community conservation is the answer in Africa, what is the question? Oryx, 35, 193-200.

Agrawal, A. \& Gibson, C.C. (1999) Enchantment and disenchantment: the role of community in natural resource conservation. World Development, 27, 629-649.

B AKER, J.E. (1997) Trophy hunting as a sustainable use of wildlife resources in southern and eastern Africa. Journal of Sustainable Tourism, 5, 306-321.

BARNES, J.I. (1999) Economic potential for biodiversity use in southern Africa: empirical evidence. Environment and Development Economics, 4, 215-220.

BARNES, J.I. (2001) Economic returns and allocation of resources in the wildlife sector of Botswana. South African Journal of Wildlife Research, 31, 141-153.

Barnes, J.I., MacGregor, J. \& Weaver, C.L. (2002) Economic efficiency and incentives for change within Namibia's community wildlife use initiatives. World Development, 30, 667-681.

Barrett, J.C. (1991) The Economic Role of Cattle in Communal Farming Systems in Zimbabwe. Pastoral Development Network paper No. 32b. Overseas Development Institute, London, UK.

BERZBORn, S. (2007) The household economy of pastoralists and wage-labourers in the Richtersveld, South Africa. Journal of Arid Environments, 70, 672-685.

Blanc, J.J., Barnes, R.F.W., Craig, G.C., Douglas-Hamilton, I., Dublin, H.T., Hart, J.A. \& Thouless, C.R. (2005) Changes in elephant numbers in major savannah populations in eastern and southern Africa. Pachyderm, 38, 19-28.

Blanc, J.J., Barnes, R.F.W., Craig, G.C., Dublin, H.T., Thouless, C.R., Douglas-Hamilton, I. \& Hart, J.A. (2007) African Elephant Status Report 2007: An Update from the African Elephant Database. Occasional Paper Series of the IUCN Species Survival Commission No. 33. IUCN, Gland, Switzerland.

Cochran, J. \& RAy, I. (2009). Equity re-examined: a study of community-based rainwater harvesting in Rajasthan, India. World Development, 37, 435-444.

Cumming, D.H.M. (1999) Living off 'biodiversity': whose land, whose resources and where? Environment and Development Economics, 4, 220-223.

Du Toit, J.T. (2002) Wildlife harvesting guidelines for communitybased wildlife management: a southern African perspective. Biodiversity and Conservation, 11, 1403-1416.

Fortmann, L., Roe, E. \& Van Eeten, M. (2001) At the threshold between governance and management: community-based natural resource management in Southern Africa. Public Administration and Development, 21, 171-185.

HACKEL, J.D. (1998) Community conservation and the future of Africa's wildlife. Conservation Biology, 13, 726-734. 
Humavindu, M.N. \& Barnes, J.I. (2003) Trophy hunting in the Namibian economy: an assessment. South African Journal of Wildlife Research, 33, 65-70.

IRDNC (Integrated Rural Development and Nature ConSERVATION) (2007) WWF/SDC Project Technical Progress Report-Caprivi. Integrated Rural Development and Nature Conservation, Katima Mulilo, Namibia.

Jones, B., Long, S.A., Murphy, C., Vaughan, K., Mulonga, S. \& Katjiua, J. (2002) Wildlife, Tourism and Livelihoods in Namibia: A Summary of Preliminary Findings. Wildlife Integration for Livelihood Diversification Project Working Paper 20. Ministry of Environment and Tourism, Windhoek, Namibia.

Jones, B. \& Murphree, M. (2001) The evolution of policy on community conservation in Namibia and Zimbabwe. In African Wildife and Livelihoods: The Promise and Performance of Community Conservation (eds D. Hulme \& M. Murphree), pp. 38-58. James Currey, Oxford, UK.

Kgathi, D.L., Kniveton, D., Ringrose, S., Turton, A.R., Vanderpost, C.H.M., Lundqvist, J. \& Seely, M. (2006) The Okavango; a river supporting its people, environment and economic development. Journal of Hydrology, 331, 3-17.

Kiss, A. (2004) Is community-based ecotourism a good use of biodiversity conservation funds? Trends in Ecology \& Evolution, 19, 232-237.

Lambin, E.F., Turner, B.L., Geist, H.J., Agbola, S.B., Angelsen, A., BRUCE, J.W. et al. (2001) The causes of land-use and landcover change: moving beyond the myths. Global Environmental Change, 11, 261-269.

Leach, M., Mearns, R. \& Scoones, I. (1999) Environmental entitlements: dynamics and institutions in community-based natural resource management. World Development, 27, 225-247.

LI, T.M. (2002) Engaging simplifications: community-based resource management, market processes and state agendas in upland South-East Asia. World Development, 30, 265-283.

Mulonga, S., Suich, H. \& Murphy, C. (2003) The Conflict Continues: Human Wildlife Conflict and Livelihoods in Caprivi. DEA Research Discussion Paper 59. Ministry of Environment and Tourism, Windhoek, Namibia.

MurombedZi, J.C. (1999) Devolution and stewardship in Zimbabwe's CAMPFIRE programme. Journal of International Development, 11, 287-293.

Murphree, M.W. (2004) Communal Approaches to Natural Resource Management in Africa: From Whence and to Where? Keynote Address for the 2004 Breslauer Graduate Student Symposium. University of California at Berkeley, Berkeley, USA.

Musumali, M.M., Larsen, T.S. \& Kaltenborn, B.P. (2007) An impasse in community-based natural resource management implementation: the case of Zambia and Botswana. Oryx, 41, 306-313.

O'Connell-Rodwell, C.E., Rodwell, T., Rice, M. \& HART, L.A. (2000) Living with the modern conservation paradigm: can agricultural communities co-exist with elephants? A five-year case study in East Caprivi, Namibia. Biological Conservation, 93, 381-391.

Osborn, F.V. \& Parker, G.E. (2003) Towards an integrated approach for reducing the conflict between elephants and people: a review of current research. Oryx, 37, 80-84.
Pero, L.V. \& S Mith, T.F. (2008). Institutional credibility and leadership: critical challenges for community-based natural resource governance in rural and remote Australia. Regional Environmental Change, 8, 15-29.

Sallu, S.M., Twyman, C. \& Thomas, D.S.G. (2009) The multidimensional nature of biodiversity and social dynamics and implications for contemporary rural livelihoods in remote Kalahari settlements, Botswana. African Journal of Ecology, 47(Suppl. 1), 110-118.

Sanderson, S.E. \& Redford, K.H. (2003) Contested relationships between biodiversity conservation and poverty alleviation. Oryx, 37, 389-390.

Skarpe, C., Aarrestad, P.A., Andreassen, H.P., Dhillion, S.S., Dimakatso, T., DU Toit, J.T. et al. (2004) The return of the giants: ecological effects of an increasing elephant population. Ambio, 33, 276-282.

TAYLOR, R. (2009) Community based natural resource management in Zimbabwe: the experience of CAMPFIRE. Biodiversity and Conservation, 18, 2563-2583.

Torquebiau, E. \& Taylor, R.D. (2009) Natural resource management by rural citizens in developing countries: innovations still required. Biodiversity and Conservation, 18, 2537-2550.

Twyman, C. (1998) Rethinking community resource management: managing resources or managing people in western Botswana? Third World Quarterly, 19, 745-770.

Twyman, C. (2000) Livelihood opportunity and diversity in Kalahari Wildlife Management Areas, Botswana: rethinking community resource management. Journal of Southern African Studies, 26, $783-806$.

Vanderpost, C. (2006) Pathways of human sprawl in wilderness buffer zones. Population and Environment, 27, 285-306.

WALKER, B. (1999) Maximising net benefits through biodiversity as a primary land use. Environment and Development Economics, $4,203-236$.

Wittemyer, G., Elsen, P., Bean, W.T., Burton, A.C.O. \& Brashares, J.S. (2008) Accelerated human population growth at protected area edges. Science, 321, 123-126.

\section{Appendices}

The appendices for this article are available online at http:// journals.cambridge.org

\section{Biographical sketches}

WILLIAM KANAPAUX's research focuses on human-environment interactions in social-ecological systems in southern Africa and the USA. He is currently a graduate research fellow with NOAA's National Estuarine Research Reserve System. BRIAN CHILD has extensive experience with community-based natural resource management programmes in southern Africa and is former chair of IUCN's Southern Africa Sustainable Use Specialist Group. 